\title{
O otwartości metafory
}

\section{Bartłomiej Maliszewski}

Uniwersytet im. Marii Curie-Skłodowskiej, Lublin bartlomiej.maliszewski@ poczta.umcs.lublin.pl

\section{Streszczenie}

Artykut dotyczy otwartości metafory ujmowanej $z$ trzech perspektyw: nadawczej (otwartość metafory jako możliwość kreowania nowych znaczeń i gier semantycznych), odbiorczej (otwartość metafory jako możliwość dokonywania mniej lub bardziej rozległych interpretacji) oraz badawczej (otwartość metafory jako nieostrość granic między znaczeniem dosłownym i przenośnym oraz coraz szerszy sposób ujmowania samego zjawiska metafory).

Stowa kluczowe: metafora, innowacja, gry językowe

\section{Abstract}

About the Openness of Metaphor

The paper discusses the openness of metaphor seen from three perspectives: from the addresser's perspective (the openness of metaphor as the possibility of creating new meanings and semantic games), the addressee's perspective (the openness of metaphor as the possibility of making more or less extensive interpretations) and the researcher's perspective (the openness of metaphor as the fuzziness of the borders between the literal and figurative meanings and the more and more extended manner of capturing the phenomenon of metaphor itself).

Keywords: metaphor, innovation, word play

\section{Wstęp}

Tytuł niniejszego artykułu jest bardzo zwięzły, co wynika z dwóch przyczyn. Po pierwsze, użyta formuła stanowi aluzję do szkicu Aleksandry Okopień-Sławińskiej: Metafora bez 
granic (1980), do którego nieraz będziemy się odwoływać ${ }^{1}$. Po drugie, lapidarność tytułowego wyrażenia sprzyja refleksji nad jego znaczeniem, czego efektem może być właśnie doświadczana otwartość metafory. To, ile treści wyczytamy z danego sformułowania, zależy wszakże od poziomu kompetencji odbiorczych i stopnia zaangażowania w proces analizy tekstu. Dla laika wyrażenie: otwartość metafory nie będzie ani dostrzegalną przenośnią, ani źródłem bogatych znaczeń. Dla kognitywisty będzie to zaś metafora, której wyjaśnienie stałoby się przedmiotem obszernego wykładu.

W niniejszym tekście omówimy problem otwartości metafory, biorąc pod uwagę perspektywę nadawczą, odbiorczą i badawczą. W pierwszym wypadku otwartość metafory definiujemy jako możliwość kreowania nowych znaczeń, wprowadzania nieszablonowych połączeń, modyfikacji utartych konstrukcji oraz rozwijania utrwalonych językowo skojarzeń (które znajdują swój wyraz w różnych kodach). W drugim wypadku otwartość metafory traktujemy jako możliwość dokonywania różnych interpretacji oraz doświadczania przenośni jako impulsu wymienionych zabiegów (w toku interakcji odbiorca wchodzi wszakże w rolę nadawcy). Otwartość metafory jako przedmiotu refleksji badawczej odnosimy zaś do problemu nieostrości granic między znaczeniami dosłownymi i przenośnymi oraz do zmieniających się definicji samego zjawiska metafory, która przestaje być ujmowana jako figura słowna (posługiwanie się nazwą jednych obiektów dla określenia innych), a staje się przedmiotem analizy jako nieodłączny składnik myślenia i rzecz, która uobecnia się w różnych kodach.

\section{Innowacyjność przenośni}

\subsection{Inaczej mówiąc - dążenia do oryginalności przekazu}

Początek refleksji nad metaforą wyznacza spostrzeżenie, że użytkownicy języka nie zawsze posługują się właściwymi określeniami pewnych obiektów - np. zamiast słowa starość pojawia się peryfraza: wieczór życia (P, 1457b; R, 1405a). Właśnie to nazywanie jednych rzeczy mianem innych zostaje obdarzone mianem metafory, a ów termin $\mathrm{u}$ Arystotelesa charakteryzuje się dość szerokim zakresem semantycznym, obejmując także to, co dziś zakwalifikowalibyśmy jako hiperonim, hiponim, metonimię czy synekdochę.

Definiując metaforę jako przeniesienie nazwy, Arystoteles koncentruje się nad dwiema kwestiami: na jakiej podstawie dochodzi do danego zabiegu oraz czemu on służy. Stagiryta wyszczególnia zatem relacje pomiędzy użytym słowem a właściwą nazwą 
obiektu, a przy omawianiu przenośni opartych na zasadzie proporcji i analogii wskazuje podobieństwa pomiędzy obiektami, o których jest mowa w metaforze. Analizując przyczyny i cele nazywania jednych rzeczy mianem innych, filozof zastrzega, że istotna jest nie tylko jasność wypowiedzi, ale i stosowność stylu. Mówca czy poeta nie powinien się ograniczać do używania skonwencjonalizowanych sformułowań, ale starać się wzbudzać uwagę słuchaczy niezwykłymi (choć jednocześnie zrozumiałymi) określeniami obiektów, postaci, czynności. Dzięki temu można unikać pospolitości stylu, wychodzić poza koleiny przewidywalnych sformułowań, układać zagadki, określać to, co nie posiada własnego miana, przypisywać przedmiotom cechy istot żywych, wyrażać przesadę, narzucać wyrazistą ocenę tematu, a także umożliwiać odbiorcy poznawanie nowych rzeczy, sprawiając mu przyjemność (R, 1404a- 1413a).

Otwartość metafory należy tu więc odnieść do trzech kwestii. Po pierwsze, każdej nazwy można użyć w znaczeniu przenośnym i nieograniczony jest zasób obiektów, które podlegają metaforycznemu określaniu. Np. nazwą Kraków możemy się posłużyć w sposób przenośny i rozliczne miasta obdarzać tym mianem na podstawie dostrzeżonego związku między dwoma obiektami. Po drugie, motywacja kreowanych przenośni jest sprawą otwartą, zależąc od celów wypowiedzi, kompetencji i błyskotliwości nadawcy. Jak bowiem zaznacza Arystoteles: „tworzenie dobrej metafory jest (...) równoznaczne z dostrzeganiem podobieństwa w rzeczach niepodobnych" (P, 1459a). Po trzecie, metafora (jako dokonywana innowacja) sprawia, że przekaz staje się bardziej otwarty na odbiorców, służąc angażowaniu ich uwagi i dostarczając im satysfakcji z poznawania nowych, zaskakujących sformułowań: „Ludzie znajdują bowiem przyjemność w tym, co ich zadziwia, a zadziwiają ich rzeczy niespotykane.” (R, 1404b). Aby pozyskać uwagę odbiorcy, trafić do jego wyobraźni, warto mówić nie tylko zrozumiale, ale i intrygująco, czemu właśnie sprzyja umiejętne posługiwanie się metaforą ${ }^{2}$.

W związku z tym, że Arystotelesowskie uwagi odnoszą się do przenośni jako niezwykłego sposobu posługiwania się językiem, ślady podobnego ujęcia metafory odnajdujemy przy omawianiu cech stylu artystycznego. Jan Parandowski w Alchemii słowa stwierdza:

Pod piórem pisarzy naznaczają sobie spotkanie słowa, które się nigdy dotąd nie spotkały, czasowniki zaciągają się w służbę nie znanych im dotąd czynności, rzeczowniki zdobywają nowy zakres władzy. Tymczasem w mowie potocznej, w lichej literaturze, w pospolitej publicystyce słowa nudzą się i dręczą w stałych związkach. Wciąż te same przymiotniki 
wloką się jak cień za swoimi rzeczownikami. Skamieniałe zwroty, spróchniałe metafory. Pleśń, rzęsa, stojąca woda.

Charakterystyce utartych sformułowań służą porównania i przenośnie, które uwydatniają (negatywnie wartościowaną) szablonowość wypowiedzi: te same przymiotniki wloka się jak cień za swoimi rzeczownikami, skamieniałe, spróchniate metafory, pleśń, stojaca woda. Twórcza przenośnia jest zaś ujmowana jako rzecz, która wprowadza ożywczy ruch wśród słów oraz ich znaczeń ${ }^{3}$, wnosząc walor niezwykłości, angażując wyobraźnię odbiorcy i pobudzając go do wysiłku interpretacyjnego.

Domeną mniej skonwencjonalizowanych przenośni jest styl artystyczny, który umożliwia największą swobodę $\mathrm{w}$ doborze środków językowych. Niemniej i wśród tekstów medialnych, których nadawcy zabiegają o uwagę masowego odbiorcy, łatwo odnaleźć przykłady dość oryginalnych sformułowań - np. w jednym z prasowych nagłówków znany pięściarz zostaje określony jako Nasz Mozart boksu (GW, 13.11.2004), a występy słynnych śpiewaczek zapowiada tytuł: Operowe tornado w Polonii (GW, 07.12.2009). Użyte sformułowania wzbudzają efekt zaskoczenia, nakazując docenić potencjał przenośni jako możliwości kreowania nowych znaczeń i połączeń wyrazowych ${ }^{4}$.

Przy omawianiu takich zaskakujących przenośni Harald Weinrich ([1963] 1971: 65) rozróżnia kontekst determinujący (typowy dla danego określenia) oraz kontekst kontrdeterminujący (nieoczekiwany, charakterystyczny właśnie dla wyrazistych przenośni). Weinrich spostrzega, że im bardziej są sprecyzowane oczekiwania odbiorcy, tym łatwiej o efekt zaskoczenia. Temu celowi dobrze więc służą określenia o bogatej treści i rozległej warstwie konotacji, gdyż ich użycie odsyła do ściśle określonych postaci, obiektów oraz sytuacji, pozwalając zadziwić odbiorcę nietypowym (kontrdeterminującym) kontekstem ${ }^{5}$ (Weinrich [1963] 1971: 66). Np. tytuł mistrza odznacza się dość ogólnikową treścią i szeroką łączliwością, a wyrażenia typu: mistrz boksu, mistrz kierownicy, mistrz słowa są dość szablonowe i nie koncentrują na sobie uwagi. Określenie wirtuoz wnosi już konkretniejszą treść, pozwalając oczekiwać przydawki, którą jest nazwa instrumentu muzycznego, a sformułowania wirtuoz boksu, wirtuoz kierownicy, wirtuoz słowa są odczuwalnymi metaforami. Kiedy zaś posłużymy się nazwiskami znanych mistrzów i powiemy np. o Mozarcie boksu, Mozarcie kierownicy czy Mozarcie słowa, pozyskamy jeszcze większą uwagę odbiorcy. Im konkretniejsza treść leksemów, tym więcej możliwości zadziwiania ich nietypowym kontekstem. 


\subsection{Otwartość utartych przenośni}

Kreatywność użytkowników języka uwidacznia się jednak nie tylko w tworzeniu nowych przenośni, ale i sposobach wykorzystywania językowo utrwalonych metafor. Aby stworzyć udaną grę językową, nie trzeba się silić na oryginalność skojarzeń. Wystarczy poprzestawać na dość banalnych asocjacjach, podążając tropem treści dosłownych i utartych połączeń wyrazowych, które pod wpływem kontekstu nabierają nowych, bogatszych treści i stają się częstym środkiem komizmu językowego ${ }^{6}$.

Źródła wykorzystywanych asocjacji można podzielić na dwa rodzaje. Jedne skojarzenia są bowiem narzucane poprzez metaforyczne nazwy poszczególnych obiektów, drugie - poprzez ich stereotypowe cechy. W pierwszym wypadku będziemy mówić o skojarzeniach nazewniczych, w drugim - o skojarzeniach rzeczowych.

Wzorcowym przykładem pierwszych asocjacji są gry odapelatywną nazwą własną - np. słysząc o panu Wilku, można wykorzystywać dwuwartościowość danego rzeczownika (jako nazwy własnej i pospolitej). Choć takie żarty nie są wyszukane, a nawet stanowią naruszenie etykiety, to jednak stanowią częsty element komizmu językowego: Ksiądz Wilk o owieczkach (GW, 04.03.2016), Wilczek chce ugryźć Spójnię (GW, 08.04.2015). W wiadomościach sportowych przedmiotem takich nazewniczych skojarzeń są zazwyczaj odapelatywne nazwy drużyn: AZS UMCS powalit Tura (GW, 23.02.2016), Arka ptynie do ekstraklasy (GW, 01.12.2015), Nie zgasili Znicza (GW, 13.02.2012), Sokót nie polatat (GW, 24.10.2011). Trzeba usidlić Sokoła (GW, 12.01.2011). Widzimy wyraźnie, że dobór konstrukcji predykatywnej zależy nie tylko od samego rodzaju określanej sytuacji, ale i konotacji znaczącej nazwy własnej, która staje się osnową gry językowej.

Impulsem podobnych zabiegów stają się również rzeczownikowe metafory apelatywne. Np. określanie kogoś mianem gwiazdy skłania do użycia czasowników odnoszących się właśnie do światła: Gwiazdy zalśnia na Globusie (GW, 27.02.2015), Gwiazdy zaświeca w Dworze Artusa (GW, 26.09.2013), Czy Polki zgasza serbska gwiazdę? (GW, 29.09.2011), a obdarzanie wojowniczo nastawionych polityków mianem jastrzębi prowokuje do użycia takich czasowników, które odnoszą się do zachowań ptaków: Jastrząb chwycit wiatr (GW, 11.03.2011), Jastrzębie zlatują się do RPP (GW, 14.01.2010), Jastrząb Cheney krąży po Zakaukaziu (GW, 04.09.2008) ${ }^{7}$.

Źródłem kolejnych skojarzeń, które prowadzą do współwystępowania różnych znaczeń, nie są już metaforyczne nazwy obiektów, lecz pewne stereotypowe cechy 
określanych przedmiotów (będziemy tu więc mówić o skojarzeniach rzeczowych). Np. wiadomość o dużych zyskach koncernu spożywczego zostaje zatytułowana Słodkie życie Nestle (GW, 01.03.2002). Aktualizując konotację użytej nazwy własnej (odnoszącej się do producenta słodyczy), zaczynamy dostrzegać nieprzypadkowość doboru właśnie takiego wyrażenia. Gdy mowa jest o politycznej działalności Garriego Kasparowa, znanego arcymistrza szachowego, wykorzystaniu podlega właśnie metafora polityki jako gry w szachy: Kasparow szachuje Putina (GW 15.04.2006), a gdy rzecz dotyczy kierowcy rajdowego, twórczemu wykorzystywaniu podlegają wykładniki metafory drogi: Nagły zakręt Roberta Kubicy (GW 30.08.2018). Jako przykład takiej gry semantycznej, której osnową jest rzeczownik pospolity, przytoczmy zdania: Ceny ropy na świecie pompuje polityka (GW 04.05.2006), Rolnicy kosza kasę (GW, 25.08.2007). Stereotypowa wiedza na temat poszczególnych postaci czy obiektów narzuca sposób metaforycznego określania danych sytuacji, uaktualniając dosłowną treść czasowników.

Gry znaczeniami różnią się stopniem wyrazistości i w niektórych wypadkach należy wyjść poza granicę samego sformułowania, by dostrzec drugą warstwę semantyczną. Np. tytuł: Stara miłość nie rdzewieje (GW, 20.12.2013) nie będzie zauważalną grą językową, dopóki nie zwrócimy uwagi, że mowa jest o zabytkowych samochodach (chronionych przed korozją). Możemy tu więc wyróżnić gry mikrokontekstowe (metaforycznie użyty człon ujawnia swoją dwuznaczność już w obrębie użytego sformułowania) oraz gry makrokontekstowe (których odczytanie wymaga uściślenia tematu).

Warto też zauważyć, że do współwystępowania różnych znaczeń leksemów prowadzi zarówno wykorzystywanie spójnych połączeń wyrazowych, jak i sprzeczności semantycznych. W pierwszym wypadku będziemy mówić o zasadzie koherencji (metaforyczny leksem jest używany w takim kontekście, który jest spójny z jego znaczeniem dosłownym), w drugim zaś - o zasadzie kontrastu (metaforyczny leksem jest umiejscawiany $\mathrm{w}$ takim kontekście, który stwarza pewien paradoks). Np. jeśli w odniesieniu do mistrzów siatkówki plażowej, użyjemy wyrażenia Gwiazdy nad morzem, zastosujemy zasadę koherencji, a gdy użyjemy sformułowania Gwiazdy na piasku, wykorzystamy regułę kontrastu. Zarówno jeden, jak i drugi sposób sprzyja koncentrowaniu uwagi odbiorcy, aktywizując dosłowną treść utartej metafory.

Kolejnym sposobem twórczego wykorzystywania skonwencjonalizowanych przenośni staje się przekształcanie utartych wyrażeń, zwrotów, fraz, przysłów. Stosowane tu zmiany obejmują bardzo szeroki repertuar środków, poczynając od nieznacznych 
modyfikacji w zakresie fleksji lub składni, dodanie, ujęcie bądź wymianę członów po derywację frazeologiczną, kontaminację frazeologizmów oraz liczne aluzje do utartych sformułowań ${ }^{8}$. Wystarczy wprowadzić pozornie niewielką zmianę, by zyskać znacznie większą uwagę odbiorcy. Np. odczytując zdanie Kruk krukowi oko wykole (GW, 06.08.2016), zapewne zatrzymamy się nad nim dłużej niż nad kanoniczną wersją przysłowia, zastanawiając się, jakiej zmiany dokonano i jaka jest jej motywacja. Tak sformułowany tytuł doskonale więc spełnia swoją rolę, służąc pozyskiwaniu uwagi odbiorcy i zachęcając do zapoznania się z treścią artykułu.

Sformułowania, które powstają poprzez wymianę członów frazeologizmu, mają zaś ten walor, że są bardzo pojemne pod względem informacyjnym, przywodząc na myśl treść utartej metafory i od razu wprowadzając w jej temat. Np. interpretując wyrażenie Bank w owczej skórze (GW, 03.09.2016), odczytujemy treść znanej przenośni (wilk w owczej skórze - 'ktoś umiejętnie skrywający swój zły charakter'), a jednocześnie zyskujemy informację, czego ona dotyczy. Tytuł Polska z motyka na Afganistan (GW, 19.08.2009) odwołuje się do znanej przenośni i od razu umiejscawia ją w określonym kontekście (polskiej misji na Bliskim Wschodzie). Poprzez wymianę członów bądź aluzję do znanych przenośni łatwo jest tworzyć niespotkane dotąd wyrażenia, a zarazem zapewniać im dużą pojemność semantyczną i narzucać wyrazistą ocenę tematu.

Skonwencjonalizowane metafory są otwarte na gry znaczeniowe także $\mathrm{z}$ tego względu, że stają się podstawą kolejnych przenośni. Np. dobrze znana gra w ruletkę posłużyła niegdyś jako punkt odniesienia dla nazwania makabrycznej gry z rewolwerem (rosyjskiej ruletki), która dziś jest z kolei przywoływana przy określaniu śmiertelnie ryzykownych sytuacji: Rosyjska ruletka na ulicy (GW, 17.07.2018), Rosyjska ruletka na polskich drogach $(G W, 25.08 .2014)$. Mamy tu więc do czynienia z przenośnią piętrową jedna nazwa służy określaniu nowego zjawiska, a powstałe wyrażenie staje się osnową kolejnej metafory, czego wskaźnikiem jest coraz większa liczba członów określających (por.: ruletka - rosyjska ruletka - rosyjska ruletka na polskich drogach).

Słownikowo utrwalone przenośnie inspirują także do tworzenia kolejnych metafor, które wywodzą się z tego samego pola znaczeniowego. W pytaniu: Kto lokomotywa, kto drezyną? (GW, 19.08.2005) znany neosemantyzm staje się impulsem, by posłużyć się metaforyczną nazwą jeszcze innego pojazdu szynowego (poprzez kontrast konotacji można zakładać, że druga przenośnia odnosi się do tych postaci, które nie odgrywają istotnej roli i nie dysponują szerokim zapleczem politycznym). Odczytując tytuł Su góra, Mig dołem (GW, 07.08.2003) w kontekście informacji o dostawie myśliwców, 
dostrzegamy dwuznaczność obu sformułowań (odwołujących się do położenia samolotów oraz wyników złożonej oferty). Oprócz wykorzystywanych skojarzeń rzeczowych także i tu dochodzi do użycia nowej przenośni. O ile stwierdzenie, że coś (jest) góra stanowi pewien szablon, o tyle konstrukcja, że coś (jest) dołem nie funkcjonuje jako językowo utrwalona fraza. Tym, co łączy derywowane znaczenie słowa drezyna oraz konstrukcję Mig dołem, jest więc to, że obie metafory powstają pod wpływem utartych przenośni i są odczytywane właśnie poprzez ich pryzmat.

Można przy tym zauważyć, że zasób utrwalonych przenośni świadczy o tym, co użytkownicy języka uznają za istotne i godne wyróżnienia. Mówimy o lokomotywach wyborczych (a nie drezynach), koncentrując uwagę na liderach silnych ugrupowań, a nie drugorzędnych postaciach bez zaplecza politycznego. Mówimy o tym, że X jest górą (a nie że Y jest dołem), skupiając się na tym, co stanowi ważniejszą wartość. Rozwijając temat wypowiedzi, możemy jednak wykorzystywać kolejne komponenty użytej struktury, dając przy tym wyraz swojej kreatywności ${ }^{9}$.

W dobie wizualności przekazów, których osnową jest zarówno słowo, jak i obraz, przejawem twórczego wykorzystywania utartych przenośni językowych są także komponenty ikoniczne, czego dobrym przykładem jest poniższa okładka:

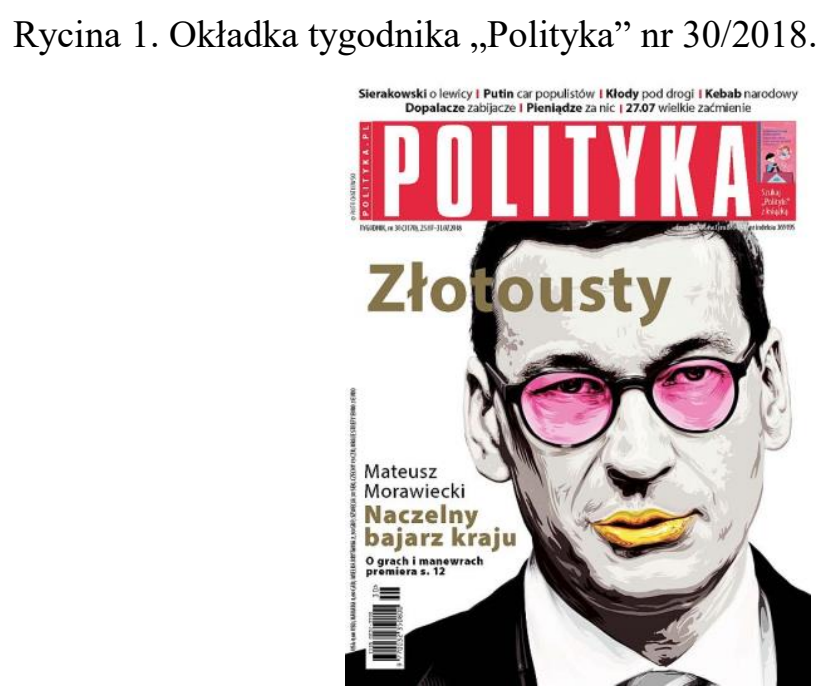

Określenie Złotousty 'umiejący pięknie mówić' zostaje udosłownione poprzez obraz, a kolejny barwny element również stanowi ujęzykowiony symbol (patrzeć na świat przez różowe okulary). Czarno-biały portret koncentruje uwagę na dwóch kolorowych komponentach, a zarazem wzbudza skojarzenia ze zdjęciami dawnych dygnitarzy (czasami PRL-u, partyjną propagandą) i konotuje szarą, bezbarwną rzeczywistość, która 
w oczach przedstawianego podmiotu i w jego wypowiedziach podlega koloryzowaniu. Interpretując dany obraz, bazujemy zatem na utrwalonych językowo skojarzeniach, które leżą u podstaw wizualnej metafory. Język jest wszakże pełen obrazowych konstrukcji, a symboliczne obrazy są w dużej mierze ujęzykowione (zob. Libura 2012).

Jak wynika z powyższych przykładów, utarta (choć nie zatarta) przenośnia stanowi impuls do gry znaczeniami (rolnicy kosza kasę), dokonywania wtórnych metaforyzacji (rosyjska ruletka na polskich drogach), modyfikowania szablonowych konstrukcji (bank w owczej skórze) oraz rozwijania skojarzeń, których wykładnikami są utrwalone językowo metafory (skoro silni liderzy list wyborczych są określani mianem lokomotyw, to niezależni i mniej znaczący kandydaci mogą być nazwani drezynami). G. Lakoff i M. Johnson spostrzegają, że słownikowe zwroty i wyrażenia są przejawem struktur pojęciowych, które wykorzystujemy w sposób cząstkowy. Tym samym metafora staje się otwarta na liczne i okazjonalne rozszerzenia utrwalonych językowo powiązań (Lakoff, Johnson [1980] 1988: 77-80).

\section{Otwartość interpretacji (interakcyjna teoria metafory)}

Otwartość metafory - ujmowana z perspektywy odbiorcy - to możliwość mniej lub bardziej dogłębnego odczytywania naddawanych treści. Im mniej skonwencjonalizowana przenośnia, tym bardziej różnorodne stają się postawy odbiorców, którzy mogą się ograniczać do dość trywialnych interpretacji bądź doświadczać metafory jako nośnika bogatych znaczeń. Aleksandra Okopień-Sławińska podsumowuje, że:

Skala możliwości semantycznego reinterpretowania i rozumienia „dziwnych” wyrażeń jest bardzo rozległa, podejrzewam, że od zera do nieskończoności. Zależy bowiem nie tylko od kontekstowo-leksykalnych motywacji wyrażenia, ale od całej sytuacji komunikacyjnej, w jakiej taka operacja przebiega, a zwłaszcza od kompetencji odbiorcy.

(Okopień-Sławińska 1980: 20)

Otwartość metafory nie jest zatem jej immanentną właściwością, lecz doświadczanym stanem rzeczy. Żeby metafora była otwarta, musimy mieć do niej pewien klucz, a jest nim właśnie nasza kompetencja. 
Możliwość coraz bardziej rozległych interpretacji metafory dobrze ukazuje teoria interakcyjna ${ }^{10}$, którą Black formułuje na podstawie kluczowego założenia I. A. Richardsa, że:

W najprostszym sformułowaniu metaforę spotykamy wówczas, gdy współdziałają dwie myśli dotyczące rzeczy różnych, opierając się na pojedynczym słowie lub zwrocie, a ich znaczenie jest owocem tego współdziałania.

(Richards, za: Black [1954] 1971: 227)

Znaczenia metafory interakcyjnej nie można zatem sprawdzić w słowniku, a odbiorca jest zobligowany do podjęcia pewnego wysiłku interpretacyjnego, aby ustalić nową treść, która powstaje na skutek połączenia (współdziałania) dwóch myśli. Jak podsumowuje Teresa Dobrzyńska, w toku odbioru żywej przenośni należy dokonać trzech rzeczy: ustalić temat przenośni, przywołać wyobrażenia związane z nośnikiem (użytym określeniem), a następnie wybrać te cechy nośnika, które można przypisać tematowi (Dobrzyńska 1994: 88). Zależnie od rodzaju dyskursu i kompetencji odbiorcy ów proces przebiega w mniej lub bardziej płynny sposób, a przy lekturze tekstów artystycznych przedmiotem napotykanych trudności bywa już pierwszy etap odbioru metafory. Ryszard Tokarski, przywołując fragment utworu poetyckiego: Czeka, patrzy na zegar swych lat, zwraca uwagę na problemy z uściśleniem obiektu danej czynności. Próby jego skonkretyzowania (np. kalendarz, lustro, album ze zdjęciami) przynależą jedynie do sfery domysłów, świadcząc właśnie o otwartości danej metafory oraz o potencjale języka jako środku wytwarzania kolejnych znaczeń (Tokarski 1989: 29).

Liczne przenośnie, które są używane w języku codziennym, odsyłają jednak do ściśle określonych obiektów, postaci czy sytuacji, a przedmiotem dociekań pozostają związki między użytym w tekście nośnikiem a tematem metafory. Np. odczytując tytuł Gotycka korona Gdańska (GW, 07.07.2006), łatwo przyjąć, że mowa o słynnej bazylice, co potwierdza kontekst danej peryfrazy. Temat metafory nie jest więc trudny do ustalenia, a doświadczana otwartość dotyczy wykorzystywanego tertium comparationis. Zależnie od wiedzy i postawy odbiorców będzie ono obejmować różne aspekty, dotycząc niezwykłej wartości obydwu obiektów (bazylika i korona jako rzecz najcenniejsza, największa ozdoba), podobieństwa ich kształtów (gotyckie sygnaturki - wierzchołki korony) oraz układu przestrzennego (bazylika i korona jako obiekty, które górują nad pewną całością). Biorąc pod uwagę kreacyjny aspekt przenośni, wypada też dodać, że użyta metafora 
personifikuje miasto, podkreślając jego majestatyczność (Gdańsk jako królewski gród, który dumnie „nosi” swoją koronę). Zgodnie z założeniami interakcyjnej teorii metafory jej interpretacja nie sprowadza się do wskazania cech, które łączą nośnik oraz temat, nakazując uwzględnić i twórczą moc metafory jako środka kreowania nowej struktury.

Istotnym walorem metafory staje się przy tym jej sugestywność - za pomocą niewielu słów czy symbolicznego obrazu można przekazywać bardzo wiele treści. Karl Bühler, omawiając metaforyczne wyrażenie król drzew, zaznacza: "Gdybym do eksplikacji sensu wyrażenia podszedł analitycznie, dodając do wyrazu drzewo niemetaforyczne przymiotniki (np. największe, najpiękniejsze, najwyższe, dominujące), musiałbym ich przytoczyć bardzo wiele, chcąc osiągnąć w przybliżeniu ten sam efekt znaczeniowy i wyobrażeniowy, jak ów osiągnięty za pomocą mieszania sfer.” (Bühler [1934] 2004, 371). Określanie gdańskiej bazyliki mianem korony także tworzy wiązkę znaczeń, których nie da się sprowadzić do literalnie używanych sformułowań (jeśli bowiem stwierdzimy, że bazylika swoim kształtem przypomina koronę, ograniczymy obszar możliwych interpretacji i umniejszymy sugestywność przekazu). Jak stwierdza M. Black: „Wypowiedzenie metaforyczne nie jest surogatem formalnego porównania ani innego wypowiedzenia literalnego, bo posiada własną wartość i możliwości.”. (Black [1954] 1971: 226).

Interpretacyjnej otwartości metafory doświadczamy w dwojaki sposób - przy samodzielnych analizach (gdy rozwijamy własne przemyślenia na temat odczytywanej metafory) bądź przy poznawaniu cudzych interpretacji (zwięzłym objaśnieniom można zarzucać powierzchowność, a z kolei przy lekturze dogłębnych interpretacji doświadczać niepełności własnych wniosków).

\section{Co jest metaforą? - otwartość perspektyw badawczych}

Zasób przenośni jest otwarty z dwóch względów. Po pierwsze, nieustannie go wzbogacamy, tworząc nowe metafory oraz dokonując modyfikacji utartych sformułowań. Po drugie, zasób przenośni poszerza się z tego względu, że odkrywamy metaforyczność dobrze znanych zwrotów i wyrażeń. Jak stwierdza H. Weinrich ([1963] 1971: 67-68), jedne przenośnie językowe nie przekraczają określonego progu pobudliwości, inne zaś wzbudzają naszą uwagę. Niemniej ów próg pobudliwości podlega zmianom, a im więcej wiemy o metaforze, tym bardziej jesteśmy na nią wrażliwi, dostrzegając jej wszechobecność w naszym myśleniu i codziennej komunikacji. 
Ze względu na wielość oraz różnorodność konstrukcji językowych zaliczanych do zbioru przenośni niełatwo dokonać ich uporządkowania. Odwołując się do monografii Antoniego Krasnowolskiego (1905), poprzestańmy na następującej klasyfikacji:

Tabela 1.

\begin{tabular}{|l|l|}
\hline \multicolumn{2}{|c|}{ metafory słownikowe } \\
\hline \multicolumn{1}{|c|}{$\begin{array}{c}\text { odnoszące się do obiektów } \\
\text { i zjawisk poznawalnych } \\
\text { zmysłowo }\end{array}$} & \multicolumn{1}{|c|}{ odnoszące się do tego, co abstrakcyjne } \\
\hline $\begin{array}{l}\text { przeniesienie nazwy z jednego obiektu } \\
\text { na drugi, np. glowa rodziny, ucho ighy, } \\
\text { skrzydto wojska }\end{array}$ & $\begin{array}{l}\text { określanie tego, co abstrakcyjne nazwami, które } \\
\text { prymarnie odnoszą się do tego, co konkretne, np. } \\
\text { pojać od 'objąć', zastanowić się od 'stanąc', osnowa, } \\
\text { watek }\end{array}$ \\
\hline $\begin{array}{l}\text { przeniesienie nazwy z jednego wrażenia } \\
\text { zmysłowego na drugie, np. szorstki glos, } \\
\text { ostry dźwięk, ciepte kolory }\end{array}$ & $\begin{array}{l}\text { lączenie przymiotników i czasowników, które } \\
\text { prymarnie odnoszą się do tego, co konkretne, z } \\
\text { rzeczownikami abstrakcyjnymi, np. gorzki żal, snuć } \\
\text { marzenia }\end{array}$ \\
\hline $\begin{array}{l}\text { animizacja obiektów jako podmiotów } \\
\text { czynności np. ogień coś obejmuje (jakby } \\
\text { ramionami), ogień trawi i zżera }\end{array}$ & $\begin{array}{l}\text { animizacja abstrakcyjnych pojęć jako podmiotów } \\
\text { czynności, np. żal kogoś bierze (chwyta, ogarnia), } \\
\text { sumienie kogoś gryzie }\end{array}$ \\
\hline & $\begin{array}{l}\text { używanie zwrotów i konstrukcji zdaniowych o } \\
\text { przenośnym znaczeniu, np. kopać pod kimś dotki }\end{array}$ \\
\hline
\end{tabular}

Ów krótki przegląd słownikowo utrwalonych znaczeń, wyrażeń, zwrotów, fraz pozwala dostrzec, jak powszechne są metafory i jak duża jest ich rozmaitość (poczynając od pojedynczych leksemów po całe konstrukcje zdaniowe).

Przy analizie skonwencjonalizowanych przenośni pojawia się istotne pytanie, gdzie przebiega granica pomiędzy treścią dosłowną a metaforyczną. Odpowiedź jest na pozór prosta: literalnie używane sformułowania odnoszą się do tego, co konkretne, namacalne, bliskie, podczas gdy metafora dotyczy tego, co bardziej abstrakcyjne, mniej znane, nowsze. Nie zawsze jednak można rozstrzygnąć, czy jeszcze mamy do czynienia ze znaczeniem literalnym, czy już z warstwą znaczeń przenośnych. A. OkopieńSławińska, wymienia dwanaście znaczeń czasownika zachodzić i - opierając się na tym przykładzie - stwierdza, że nie mamy do czynienia z binarną opozycją użyć dosłownych i metaforycznych, ale rozciągłą skalą powiązanych ze sobą zjawisk (Okopień-Sławińska 1980: 12-15).

Wypada jednak zauważyć, że im konkretniejsza jest treść zwrotów i wyrażeń, które odnoszą się do abstrakcyjnych tematów, tym wyraźniejszy staje się ich metaforyczny 
status. Trudno wszakże rozstrzygnąć, czy używany w kontekście działań werbalnych zwrot atakować kogoś pytaniami jest przykładem przenośni językowej (i czy definicyjną cechą ataku jest użycie siły fizycznej). Dopiero konkretniejsze zwroty: bombardować kogoś pytaniami, wziąć kogoś w krzyżowy ogień pytań stanowią już dostrzegalne metafory, pozostając jednak wykładnikiem podobnego ujęcia danej sytuacji (podejmowanych działań jako ataku) ${ }^{11}$. Przenośnie językowe należy więc rozpatrywać w dwóch wymiarach - w odniesieniu do ukonkretnianego tematu oraz w relacji do innych konstrukcji językowych (wyróżniając hiperonimy, hiponimy, synonimy, antonimy omawianych sformułowań), gdyż właśnie $\mathrm{w}$ ten sposób można ukazywać regularność oraz powtarzalność wykorzystywanych powiązań między tym, co abstrakcyjne i konkretne.

Kolejną kwestią, która stwarza problemy przy omawianiu utartych przenośni, jest pytanie o ich genezę. Choćby na podstawie własnych doświadczeń łatwo zauważyć, że w jednych sytuacjach określamy jedną rzecz mianem innej na mocy świadomie wykorzystywanej metafory, hiperboli, żartu językowego, a w innych sytuacjach „nadużywamy” pewnych nazw z tego prostego względu, że nie rozgraniczamy obiektów określanych wspólnym mianem (i dopiero w chwili autorefleksji zwracamy uwagę na to, że jednej nazwy używamy wobec różnych przedmiotów).

Podobnie rzecz się ma $\mathrm{z}$ językowo utrwalonymi przenośniami. Pewne sformułowania powstają już jako odczuwalne metafory (np. wyrażenie mysz komputerowa wywoływało efekt komiczny), a inne sformułowania dopiero $\mathrm{z}$ czasem stają się dostrzegalnymi przenośniami. Giambattista Vico głosi pogląd, że mówiono np. o zębach piły, gdyż nie uwzględniano różnicy pomiędzy zębami człowieka, zwierzęcia czy narzędzi, a w konsekwencji nie uświadamiano sobie odmiennych znaczeń używanej nazwy (Vico [1725] 1966: 186-189) ${ }^{12}$. Zwroty typu: ogień coś obejmuje, ogień coś trawi także nie musiały być traktowane jako metafory, wynikając z animizacji świata przyrody i antropomorficznego postrzegania rzeczywistości ${ }^{13}$.

Zresztą i we współczesnych sposobach użycia języka znajdują swój wyraz odmienne sposoby ujmowania świata. Odczytując tytuł: Nakarmiłam ogień (GW, 02.11.2002), można dostrzec w nim przenośnię, ale - biorąc pod uwagę fakt, że ów wyeksponowany zwrot zapowiada rozmowę z badaczką syberyjskiego szamanizmu wypada przyjąć dosłowną interpretację i uznać, że ogień jest dla kogoś żywą istotą, którą się karmi. Przy decydowaniu o tym, co jest metaforą, warto więc uwzględniać perspektywę nadawcy oraz odmienność sposobów postrzegania rzeczywistości pozajęzykowej. Zwroty oraz wyrażenia, które dziś uważamy za „metafory genetyczne”, 
dla naszych przodków wcale nie musiały być przenośniami (por. Mayenowa [1974] 2000: 56).

W obecnej dobie - pod wpływem kognitywnego ujęcia Lakoffa i Johnsona - zasób konstrukcji językowych, które są uważane za metafory, znacznie się rozszerzył. Badacze, akcentując wszechobecność przenośni (reifikacji, animizacji) w myśleniu oraz w języku, zarazem uczulają odbiorców na metaforyczność zwykłych sformułowań. Po lekturze Metaphors we live by zyskujemy świadomość, że zwroty: mieć czas, prosić kogoś o cierpliwość, skorzystać $z$ okazji to metafory, które stanowią przejaw reifikacji abstrakcyjnych pojęć (jako obiektów czynności, rzeczy wartościowych) i zdajemy sobie sprawę z tego, że wyrażenia: $w$ podróży, $w$ wyścigu, $w$ euforii są metaforami, które polegają na przenoszeniu opozycji przestrzennej $w$ - poza na liczne przedmioty, stany, działania (Lakoff, Johnson [1980] 1988: 52-55).

Istotnej zmianie podlega przy tym sposób rozumienia przenośni, która zostaje umiejscowiona ponad poziomem słów i podlega zdefiniowaniu jako zjawisko pojęciowe, które znajduje swoje wykładniki w różnych kodach komunikacji. Wypowiedzi językowe stanowią zaś najbardziej rozległą i łatwo dostępną bazę danych o tym, jakim metaforami posługujemy się w naszym myśleniu i działaniu (Lakoff, Johnson [1980] 1988: 25-27). Kolejnym wyróżnikiem kognitywnego ujęcia przenośni jest akcentowana niezbywalność metafory jako środka ujmowania abstrakcyjnych tematów oraz ukazywanie systematycznych powiązań pomiędzy abstrakcyjną domeną docelową i konkretną domeną źródłową (Lakoff 1987: 276; Jäkel [1997] 2003: 43). Wyodrębnianie ogólnikowo określanych struktur konceptualnych nie sprzyja jednak analizie poszczególnych sformułowań, które bywają przedmiotem bardzo arbitralnych kategoryzacji ${ }^{14}$.

Dokładniejszą analizę metafory jako zjawiska pojęciowego umożliwia zaś model amalgamatu G. Fauconniera i M. Turnera ([1996] 2001). Zgodnie z tym ujęciem metafora jest wykładnikiem przestrzeni amalgamatu, która powstaje na skutek łączenia co najmniej dwóch przestrzeni wejściowych o wspólnej przestrzeni generycznej (np. mówiąc o bombardowaniu kogoś pytaniami łączymy ze sobą dwie sceny o podobnej strukturze: napastliwe zadawanie licznych pytań zostaje skojarzone z wyrazistą czynnością bombardowania, ostrzeliwania pewnego obiektu, a efektem łączenia obu przestrzeni jest reifikacja pytań jako narzędzi ataku oraz jego hiperboliczne ujęcie - obiekt działania jawi się jako ofiara zmasowanej napaści, lecz rozumiemy, że nie dochodzi tu do żadnego kontaktu fizycznego i niebezpieczeństwa utraty życia). Stosując model amalgamatu, można zwracać uwagę na podkreślaną przez Lakoffa i Johnsona systematyczność 
metaforycznych powiązań oraz ucieleśnianie tego, co abstrakcyjne, a zarazem skupiać się na poszczególnych metaforach jako wykładnikach nowej struktury, która powstaje w efekcie łączenia co najmniej dwóch przestrzeni mentalnych (a im konkretniejsza metafora, tym łatwiej dostrzegalny i bardziej złożony jest proces integracji pojęciowej).

W świetle traktowania metafory jako mechanizmu poznawczego konstatacja, że przenośnia polega na określaniu jednej rzeczy mianem innej, jawi się dziś jako wierzchołek góry lodowej. Zmieniające się ujęcia badawcze nakazują też dostrzec fakt, że w rozwoju refleksji nad metaforą wciąż znajdujemy się na pewnym etapie wiedzy o jej mechanizmach, a dynamiczny rozwój nauk kognitywnych będzie prowadzić do dalszych uzupełnień oraz modyfikacji obecnych teorii.

\section{Wnioski}

W niniejszym artykule staraliśmy się omówić problem otwartości metafory z trzech perspektyw: nadawczej, odbiorczej i badawczej. W każdej z nich przenośnia ujawnia swój bogaty potencjał. Użytkownicy języka tworzą kolejne metafory, modyfikują utarte sformułowania i posługują się przenośnią w różnych kodach komunikacji, w mniej lub bardziej dogłębny sposób interpretując znaczenia metaforycznych przekazów. Najbardziej znani teoretycy przenośni nie poprzestają zaś na założeniach swoich poprzedników, lecz wytyczają coraz szersze horyzonty badań nad metaforą. Otwartość ujęć badawczych to jednak nie tylko przedstawianie nowych punktów widzenia, ale i możliwość odwoływania się do dawnych teorii, wśród których odnajdujemy cenne uwagi na temat metafory jako środka ujmowania rzeczywistości oraz narzędzia komunikacji.

\section{Przypisy}

\footnotetext{
${ }^{1} \mathrm{~W}$ związku z tym, że ów artykuł został opublikowany niemal 40 lat temu a w ostatnich dziesięcioleciach pod wpływem teorii kognitywnych zmienił się sposób ujmowania przenośni, problem jej otwartości warto podjąć na nowo, uwzględniając kolejne teorie.

${ }^{2}$ Wskaźnikiem atrakcyjności nowych przenośni staje się ich zapożyczanie - np. odnowa relacji pomiędzy USA a Rosją była określana przez amerykańskich polityków jako reset, a użyta metafora została spopularyzowana przez media: Rosji reset się optaci (GW, 20.11.2010) i zaczęła być stosowana w odniesieniu do odnowy relacji między kolejnymi krajami: Reset z Litwą... którego nie będzie (GW, 13.07.2012). Napotykając nową, atrakcyjną metaforę, możemy nie tylko zwrócić na nią uwagę, ale i zacząć jej używać w swoich wypowiedziach oraz kolejnych kontekstach.

${ }^{3}$ H. Kurkowska i S. Skorupka zastrzegają jednak, że przekraczanie norm semantyczno-frazeologicznych „,nie jest koniecznym warunkiem, od którego wyłącznie miałoby zależeć piękno języka, nawet piękno języka utworu literackiego.” (Kurkowska, Skorupka [1959] 2001: 15-16)
} 
${ }^{4}$ D. Buttler, omawiając metaforykę prasową, stwierdza, że: „metafora publicystyczna nieustannie oscyluje między oryginalnością, niecodziennością skojarzeń, zapewniającą ekspresywność - i odwoływaniem się do powszechnie znanych, 'oczywistych' związków między realiami, co z kolei gwarantuje jej maksymalną komunikatywność. (Buttler 1961: 441). Ów wniosek można też odnieść i do innych przenośni, których celem jest pozyskiwanie uwagi odbiorców i narzucanie wyrazistej oceny tematu.

${ }^{5}$ Podawanym tu przykładem jest określanie Balzaca mianem Napoleona listów (Weinrich [1963] 1971: 66).

${ }^{6}$ Istotne jest tu rozróżnienie pomiędzy polisemią (jako wieloznacznością wyrazu w systemie językowym) a współwystępowaniem różnych znaczeń leksemu w odczytywanych komunikatach, co A. Kiklewicz określa mianem parasemii (Kiklewicz 2006: 11). Mechanizmy aktualizowanej wieloznaczności podlegają dość dokładnemu omówieniu w pracach poświęconych humorowi językowemu (Buttler [1968] 2001: 280-281).

${ }^{7}$ Jak wynika z przytoczonych konstrukcji, tworzone w ten sposób gry semantyczne obejmują dwa komponenty wypowiedzi zdaniowej (zarówno argument, jak i predykat), choć nie jest to regułą, a różne znaczenia metaforycznych rzeczowników bywają uaktualnianie poprzez ogólnikowy kontekst. Np. zdanie: Zobaczymy gwiazdy użyte w zapowiedzi meczu piłkarskiego nabiera dwojakiej treści, choć sam czasownik nie jest dwuznaczny (jest to zatem inna sytuacja niż w wypadku zdań typu: Zaświeca gwiazdy, których oba człony charakteryzują się dwuwarstwową treścią).

8 Powyższe zjawiska wyodrębnia i szeroko omawia A. Pajdzińska, analizując sposoby wykorzystywania frazeologizmów we współczesnych tekstach poetyckich (Pajdzińska 1993).

${ }^{9}$ Modyfikowanie znaczeń leksemów oraz przekształcenia utartych sformułowań nie dotyczą oczywiście samych przenośni, ale i literalnie używanych konstrukcji. Język, którym posługujemy się w mniej sformalizowanych sytuacjach, staje się częstym źródłem żartów słownych, które pogłębiają problemy z tłumaczeniem werbalnych i wizualno-werbalnych przekazów (zob. Tabakowska 2016).

10 Podobnie i model metafory G. Fauconniera oraz M. Turnera jako amalgamatu pojęciowego skłania do poszukiwań tego, co jest wspólne łączonym przestrzeniom oraz traktowania przenośni jako przejawu nowej struktury pojęciowej.

11 Nieostrość granic pomiędzy metaforą a subkategoryzacją, warstwą znaczeń dosłownych i metaforycznych zaznaczają też językoznawcy kognitywni - zob. Lakoff, Johnson [1980] 1988: 111, Jäkel [1997] 2003: 51-52.

12 Podobne stanowisko zajmuje Wundt, stwierdzając, że: „Nogi stołu były uważane za rzeczywiste nogi, które odpowiadały kształtem kończynom ludzkim i zwierzęcym, zmartwienie było rzeczywiście odczuwane jako ciężar itd.”. (H. Wundt, za: Kurkowska, Skorupka [1959] 2001: 183-184).

${ }^{13}$ Ów problem akcentuje Jerzy Bartmiński, stwierdzając, że sformułowania: ziemia rodzi, słońce się raduje, ogień się gniewa mogą być metaforami bądź refleksami myślenia mitologicznego. Aby określić status tychże zwrotów, należy zbadać sposoby zachowania się użytkowników języka wobec ziemi, słońca, ognia (Bartmiński 2015: 2526).

${ }^{14}$ Na przykład zwroty użyte w zdaniach: To, co on powiedział, pozostawiło we mnie niesmak. Nie jestem w stanie przetrawić tych wszystkich faktów. Ta myśl dojrzewa już od wielu lat. są przedstawiane jako wykładniki struktury pojęciowej: WYOBRAŻENIA TO POŻYWIENIE. Widzimy jednak, że są to metafory, które są wykładnikiem różnorodnych powiązań - gdy mowa jest o odczuciach wywoływanych przez przyjemne bądź przykre sytuacje, pojawiają się metafory doznań smakowych, np.: gorzka przegrana, słodka zemsta, trudności ze zrozumieniem czegoś przywodzą na myśl problemy związane z przyswajaniem pokarmów i przełamywaniem przeszkód (można rozgryźć zagadkę, mieć twardy orzech do zgryzienia), a proces osiągania bardziej złożonego i doskonalszego stanu podlega ukonkretnieniu jako proces dojrzewania, nabierania smaku. Ogólnikowość używanych formuł, którymi są ujmowane metafory o różnych tematach i motywacjach, znacznie ułatwia proces dokonywanych kategoryzacji, lecz umniejsza ich wartość badawczą (zob. Pawelec 2005, 2006, Kiklewicz 2012).

\section{Wykaz skrótów}

$$
\begin{aligned}
& \text { GW - „Gazeta Wyborcza” } \\
& \text { P - Arystoteles, Poetyka } \\
& \text { R - Arystoteles, Retoryka }
\end{aligned}
$$




\section{Bibliografia}

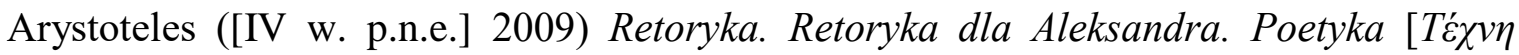
 Podbielski. Warszawa: Państwowe Wydawnictwo Naukowe.

Bartmiński, Jerzy (2015) „Perspektywa semazjologiczna i onomazjologiczna w badaniach językowego obrazu świata”. Poradnik Językowy 1 (720); 14-29.

Black, Max ([1954] 1971) „Metafora” [“Metaphor”. Proceedings of the Aristotelian Society (55/1954-1955)] (tłum.) Józef Japola. Pamiętnik Literacki 62/3; 217-234.

Buttler, Danuta (1961) „O metaforyce prasowej”. Poradnik Językowy 10 (195); 440-462.

Buttler, Danuta ([1968] 2001) Polski dowcip językowy. Warszawa: Państwowe Wydawnictwo Naukowe.

Bühler, Karl L. ([1934] 2004), Teoria języka. [Sprachtheorie. Jena: Gustav Fischer]. (thum.) Jan Koźbiał. Kraków: Universitas.

Dobrzyńska, Teresa (1994) Mówiąc przenośnie... Studia o metaforze. Warszawa: Państwowy Instytut Wydawniczy.

Fauconnier, Gilles, Mark Turner ([1996] 2001) „Tworzenie amalgamatów jako jeden z głównych procesów w gramatyce”. [„Blending as a Central Process of Grammar”. [W:] Adele Goldberg (ed.) Conceptual Structure, Discourse and Language. Stanford: Centre For The Study Of Language \& Information] (tłum.) Wojciech Kubiński, Danuta Stanulewicz. [W:] Wojciech Kubiński, Danuta Stanulewicz (red.) Językoznawstwo kognitywne II. Zjawiska pragmatyczne. Gdańsk: Wydawnictwo Uniwersytetu Gdańskiego; 173-174.

Jäkel, Olaf ([1997] 2003) Metafory w abstrakcyjnych domenach dyskursu: kognitywnolingwistyczna analiza metaforycznych modeli aktywności umysłowej, gospodarki $i$ nauki. [Metaphern in abstrakten Diskurs-Domänen. Eine kognitiv-linguistische Untersuchung anhand der Bereiche Geistestätigkeit, Wirtschaft und Wissenschaft, Frankfurt am Main: Lang] (tłum.) Monika Banaś, Bronisław Drąg. Kraków: Universitas.

Kiklewicz, Aleksander (2006), „Dyfuzja semantyczna w języku i tekście II”, LingVaria, 2 (rok I, 2006); 9-20. 
Kiklewicz, Aleksander (2012) Znaczenie w języku - znaczenie w umyśle. Krytyczna analiza współczesnych teorii semantyki lingwistycznej. Olsztyn: CBEW.

Krasnowolski, Antoni (1905) Przenośnie mowy potocznej, t. 1. Warszawa: Wydawnictwo M. Arcta.

Kurkowska, Halina, Stanisław Skorupka ([1959] 2001) Stylistyka polska. Warszawa: Wydawnictwo Naukowe PWN.

Lakoff, George, Mark Johnson ([1980] 1988) Metafory w naszym życiu. [Metaphors We Live By. Chicago: University of Chicago Press] (tłum.) Tomasz Paweł Krzeszowski. Warszawa: Państwowe Wydawnictwo Naukowe.

Lakoff, George (1987) Woman, Fire, and Dangerous Things: What Categories Reveal about the Mind. Chicago: The University of Chicago Press.

Libura, Agnieszka (2012) „Teoria metafory pojęciowej wobec badań nad komunikacją multimodalną". [W:] Monika Cichmińska, Iza Matusiak-Kempa (red.) Nowe zjawiska $w$ języku, tekście i komunikacji IV. Metafory $i$ amalgamaty pojęciowe. Olsztyn: Wydawnictwo UWM.

Mayenowa, Maria R. ([1974] 2000) Poetyka teoretyczna. Zagadnienia języka. Wrocław: Zakład Narodowy im. Ossolińskich.

Okopień-Sławińska, Aleksandra (1980) „Metafora bez granic”. Teksty: teoria literatury, krytyka, interpretacja, 6 (54); 3-35.

Pajdzińska, Anna (1993) Frazeologizmy jako tworzywo współczesnej poezji. Lublin: Agencja Wydawniczo-Handlowa.

Parandowski, Jan ([1951] 1986) Alchemia słowa. Warszawa: Czytelnik.

Pawelec, Andrzej (2005) Znaczenie ucieleśnione: propozycje kręgu Lakoffa. Kraków:

Universitas.

Pawelec, Andrzej (2006) Metafora pojęciowa a tradycja. Kraków: Universitas.

Tabakowska, Elżbieta (2016) „Co tłumaczy tłumacz? Myśl, język, kultura”. Pótrocznik Językoznawczy Tertium 1 (1-2/2016); 180-191.

Tokarski, Ryszard (1989) „Zagadki: metafory: gry językowe“. Język Artystyczny 6; 16-31. Vico, Giambattista ([1725] 1966) Nauka nowa. [La scienza nuova. Napoli: Felice Mosca] (thum.) Jan Jakubowicz. Warszawa: Wydawnictwo Naukowe PWN.

Weinrich, Harald ([1963] 1971) „Semantyka śmiałej metafory”. [“Semantik der kühnen Metapher". Deutsche Vierteljahrsschrift für Literaturwissenschaft und 
Geistesgeschichte (37/1963)] (tłum.) Ryszard Handke. Pamiętnik Literacki 62/4; 243 264. 